\title{
The Plant That Can Sink Your Mortgage Ice Cream
}

\section{Cooking Sections}

[NOTE: the terms 'native', 'non-native', 'alien' and 'invasive' are in inverted commas to remind the reader of their subjective definition.]

In July 2013 lab technician Kenneth McRae murdered his wife Jane before killing himself in the West Midlands. ${ }^{1}$ He was reported to have gone mad after finding out that Japanese knotweed was growing under his house, spreading from the nearby golf course into his property. However, no knotweed was found in the property after the fatal murder. In February 2016, William Jones hanged himself after being notified that the land he owned also

1 'Kenneth McRae Killed Wife Jane and then Himself Over Knotweed Fears', BBC News, 13 October 2015, http://www.bbc.co.uk/news/ukengland-birmingham-34515446. 
had the same plant growing on site. ${ }^{2}$ How have we come to a point in time, when an edible plant is the instigator for paranoia-driven deaths? Can a sense of taste for the plant challenge the status quo of its 'crime-inducing' tendencies?

Japanese knotweed (Fallopia japonica) and other 'nonnative' species, like Himalayan balsam (Impatiens glandulifera), rhododendron (Rhododendron ponticum) and giant hogweed (Heracleum sphondylium) have been at the forefront of a war against non-human 'invaders' in Northern Europe, and specially in the UK. These plants have been accused of taking over land, property, and the 'natural' environment.

Japanese knotweed in particular can allegedly penetrate through the foundations of a house by growing $6 \mathrm{~cm}$ per day. ${ }^{3}$ According to Eco Control Solutions, one of the lucrative knotweed eradication companies operating in the country, the plant can cause: a reduction in land value; damage to foundations and structures; damage to road surfaces; damage to walls; and a monoculture swamping out 'native' vegetation. ${ }^{4}$

Statements over the destructive or invasive character of the plant can nonetheless be contested. As James Dickson and John Bailey have widely published, there is no empirical evidence proving that the plant is as destructive and

2 'Stourbridge Man Killed Himself Over Japanese Knotweed Fears', Express and Star, 24 February 2016.

3 Eco Control Solutions, 12 December 2012, https://www.expressandstar.com/news/2016/02/24/stourbridge-man-killed-himselfover-japanese-knotweed-fears/\#Gp2FclSEvukiExWA.99.

4 Ibid. 


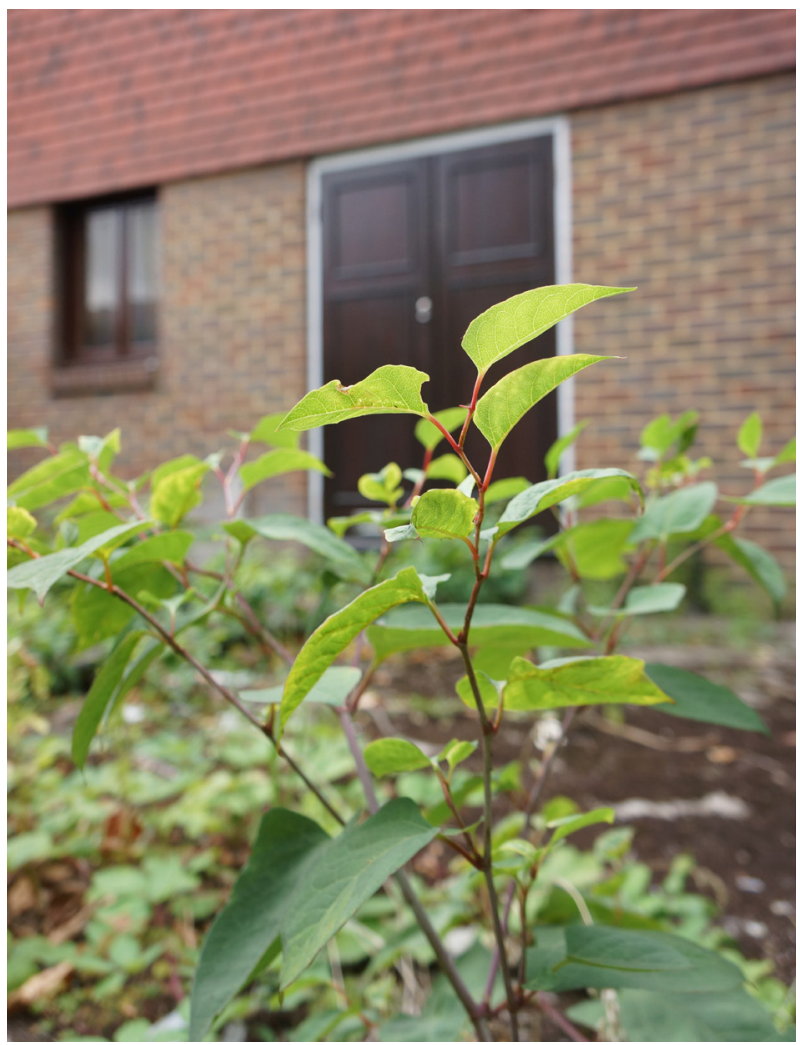

Figure $1^{5}$

'invasive' as the media claim. ${ }^{6}$ Indeed, the introduction of 'non-native' species has almost always increased the

${ }^{5}$ Japanese knotweed growing in front of a derelict property, London SE16. Photo: the authors, 2016.

${ }^{6}$ See Bailey, J.P. \& Conolly, A.P. (2000); Dickson, J.H. (1998); and Dickson, J.H., Macpherson, P. \& Watson, K. (2000). 
number of species in a region. ${ }^{7}$ The urgency to dismantle the subjectivity embedded in the perception and the laws around 'non-native' 'invasive' plants could decrease the violence upon both humans and the built environment.

Before people started taking their life - traumatised by the plant rendering their property worthless - the British government allocated extraordinary budgets to try and solve the problem of plants from elsewhere invading' us here and now. In preparation for the 2012 Olympic Games, $£ 100$ million was spent into the clearance of the Olympic site. ${ }^{8}$ The total cost to handle Japanese knotweed and other 'invaders' for British taxpayers adds up to $£ 250$ million a year. At a global scale, it is estimated that the expenditure on mitigation and eradication programmes exceeds $£ 1.4$ trillion. ${ }^{9}$

In the 2000s Japanese knotweed turned from a horticultural problem into a mediatic event. Academic journals, broadsheets and tabloids reported the 'great invasion. ${ }^{10}$ They portrayed an environmental challenge in war paint, declaring a battle to save the 'pristine' British landscape. The language deployed threatened the overarching power

Mark A. Davis et al., 'Don't Judge Species on Their Origins', Nature 474 (2011): 153-154; Mark Davis, Invasion Biology (Oxford: Oxford University Press, 2009).

8 Adam Whitehall, 'Japanese Knotweed: Government to Issue Asbos to Those Who Fail to Deal with Invasive Plant', The Independent, 19 November 2014, http://www.independent.co.uk/news/uk/homenews/japanese-knotweed-government-to-issue-asbos-to-thosewho-fail-to-deal-with-invasive-plant-species-9870356.html.

9 David Pimentel et al., 'Economic and Environmental Threats of Alien Plant, Animal, and Microbe Invasions', Agriculture, Ecosystems and Environment 84 (2001): 1-20.

${ }^{10}$ See Environet Media, http://www.environetuk.com/Media. 
of real estate value with headlines like the following: 'The Garden Invader That Could Sink Your Mortgage,' 'The Invader, If It Is in Your Garden Panic Now', 'At War With Aliens', 'Hidden Threat', 'Japanese Knotweed Invasion Causes Hertfordshire Home Price Drop', 'The Plant That Could Cost You Your Home, 'Horror Weed on Rampage' or 'Knot in My Backyard."1

Despite endless variations of similar phrases, fear has not been caused by the mere presence of Japanese knotweed; it is rather banks and environmental laws that have made people panic. Any trace of the plant in one's property can result in the refusal to grant a mortgage or a planning permission. By putting real estate market and property value under the threat of a plant, a new industry of fear was immediately born. Knotweed has even been declared as 'indisputably the UK's most aggressive, destructive and invasive plant. ${ }^{12}$ As a result, the Law Society Property Information Form requires sellers and buyers to declare whether the property on sale is affected by it. ${ }^{13}$

To question the criminalisation of Japanese knotweed, it is crucial to understand first the edible condition of the plant in its country of origin, where far from being a pest, is part of a popular consumption cycle. In the volcanic soils of mountainous regions in Japan, knotweed (itadori, 虎杖, イタドリ) has flourished for centuries. Like many other plants in the Polygonaceae family - rhubarb, sorrel, sea grapes - knotweed is enjoyed savoury or sweet in a

\footnotetext{
11 See the Newspaper Articles subsection in the list of references.

${ }^{12}$ Fred Pearce, The New Wild: Why Invasive Species Will Be Nature's Salvation (London: Icon Book, 2015).

13 The Law Society, 'Property Information Form TA6', Question 7.8.
} 
number of dishes and teas. In villages around Seki, Gifu Prefecture, it is widely foraged and used as a delicate ingredient, and some turn its stems into jam preserves. Not only has a sense of taste for the plant developed over centuries among humans; even some insects, like the psyllid Aphalara itadori, are dependent on those same juicy stems for their diet and also lay eggs on them. Having detected that these insects limit the growth by devouring the plant, British scientists are currently experimenting with importing these 'natural eaters' of the plant to release them in affected areas as a form of biocontrol. ${ }^{14}$

Unlike most crops, knotweed thrives in volcanic ashes and chemical-rich soils as it absorbs all sorts of minerals coming from the inner core of the Earth. In that sense, the original volcanic landscape of Japan shares many similarities with urban wastelands and grey zones that have been contaminated with heavy metals for decades. They both provide digestible strata for knotweed. Furthermore, the decline of ports, factories, dumpsites, landfills, road sides, and train tracks in British post-industrial cities made them the ideal sites for the appearance of knotweed - with soils contaminated by lead, copper, iron, nickel, sulphur - all similar in composition to volcanic soils in Japan. If we compare a chronological series of maps showing the spread of the plant nationwide, they expose how the geography of the thriving plant followed the appearance of wastelands resulting from

14 Japanese Knotweed Alliance CABI, 'Establishing the Psyllid: Field Studies for the Biological Control of Japanese Knotweed', http:// www.cabi.org/projects/project/32999 
de-industrialisation processes in the country. ${ }^{15}$ In nondesigned landscapes, where nothing else is planted, knotweed reveals its anthropogenic nature: far from looking 'naturally' edible, it is immediately associated with manmade toxic grounds.

Public perception of plants does not result from any scientific taxonomy of species, as classification criteria do not revolve around leaves being short or long, green or red. Subjective classifications according to cultural standards of belonging, citizenship, fair play and morality do not contribute to an objective understanding of ecology. ${ }^{16}$ Public perception is inherently constructed and based around the subjective making of belonging and Othering: entitling a plant to befit a certain place and time or excluding it from being part of it. ${ }^{17}$ Distance and proximity in this sense are continuously transformed for different purposes and economic interests. Far from scientifically objective taxonomies, determining when a subject becomes 'invasive,' or eventually 'naturalised,' depends on the artificial definition of spatial and time boundaries. Borders should be enough to determine whether a 'native' species belongs to a specific nation-state. Nonetheless, changes and redefinition of national boundaries, such as Scotland or Catalonia potentially becoming fully

15 See Chris D. Preston, David A. Pearman and Trevor D. Dines, New Atlas of the British and Irish Flora (Oxford: Oxford University Press, 2002); and John Bailey, public lecture at CCA Glasgow, 6 May 2016.

16 Davis, 'Don't Judge Species on Their Origins'.

17 Ian Rotherham and Robert Lambert (eds.), Invasive and Introduced Plants and Animals: Human Perceptions, Attitudes and Approaches to Management (London: Routledge, 2013). 
independent nation-states affect the multiple interpretations of 'native' and 'non-native' entities.

Identifying when an 'alien' arrived or became naturalised is crucial to determine its 'native' character. The amount of years that a species has inhabited a certain place should be enough to determine its degree of belonging. But is the threshold 3 years, 30 years, 300 years, 3,000 years or 30,000 years? Over the past two centuries the planet has experienced an incomparable movement of species across the globe. As Ian Rotherham and Robert Lambert claim, if we were to consider a longer time perspective, most 'native' flora could actually be referred to as 'alien' invaders. ${ }^{18}$ Notable examples are potatoes and tomatoes, brought to Europe from the Americas, that despite being 'non-native' crops eventually 'took over' the Mediterranean and Northern European diets as staple foods.

The preference for biodiversity over bio-uniformity is a cultural construct of recent times, and the notion that 'alien' species are enemies of biodiversity is a relatively modern idea. ${ }^{19}$ Not only the definition of 'native' or 'nonnative' is challenging, but the association of the 'alien' as a negative agent plays a crucial role in that distinction. English botanist John Henslow first outlined the concept of 'ecological nativeness' in 1835; and by the late 1840s, botanists had adapted the terms 'native' and 'alien' from common law to help them distinguish those plants that

18 Ibid.

19 Chris Smout, 'How the Concept of Alien Species Emerged and Developed in 20th-Century Britain', in Rotherham \& Lambert, Invasive and Introduced Plants and Animals, 55-56. 
composed a 'true' British flora from other artefacts. ${ }^{20}$ Despite referring to plants and animals, the language deployed in their classifications did seriously influence discourses on human migration. The right to travel and settle in Britain was exercised freely until the end of the nineteenth century. Even if passports were introduced in 1858 , they were more a matter of convenience for those traveling abroad, rather than means of population control. There was little control over new immigrants rights to settle in Britain. With massive immigration from Eastern Europe during the 1890s, perceptions of foreigners started to shift, as recorded in the growing accounts of racism and xenophobia. The fear of the other resulted in the passing of the 1905 Aliens Act, which started applying immigration quotas for the first time. Unsurprisingly, around the same time residents of turn-of-the-century London started to complain about Japanese knotweed 'invading' their properties.

Charles Elton's post-Second World War writing on The Ecology of Invasions by Animals and Plants is considered the pillar of 'invasive' ecology. If before the war, Elton was promoting 'exotic' species to be generally tolerated; during the Second World War, he worked as part of the war science team to prevent imports of foreign pests and diseases into Britain. ${ }^{21}$ Elton drastically shifted his practice from welcoming new plants to promoting 'botanical nationalism', whereby the taxonomy of 'non-native' species

\footnotetext{
${ }^{20}$ Davis, 'Don't Judge Species on Their Origins'.

${ }^{21}$ Rotherham and Lambert, Invasive and Introduced Plants and Animals.
} 
radically exacerbated the idea of a national landscape. ${ }^{22}$ More recently, the Wildlife and Countryside Act 1981 banned the release of 'non-native' species into the wild; the Environmental Protection Act 1990 classed Japanese knotweed as a 'controlled waste' and required that it be disposed safely at licensed landfill sites; the Wildlife and Natural Environment (Scotland) Act 2011 criminalised the spread of 'invasive' plants; the 2014 Wildlife Law: Control of Invasive Non-Native Species and the Infrastructure Act 2015 allowed right of access to private land for eradication of 'invasive' 'alien' species. Yet, if we were to be strict and environmentally rigorous about how damaging some plants are to 'native' flora, the multimillion British timber sector, for instance, would need to seriously rethink monoculture 'forests' that are economically profitable, yet 'nonnative' and environmentally disruptive. Hence, a more flexible and environmentally sound notion of 'native' and 'invasive' is urgently required.

Scaremongering campaigns have produced images of Japanese knotweed dramatising the 'destructive' properties of the plant. Widely circulating online, this imagery aims to proof how the plant penetrates walls, roofs and floors, and depicts how knotweed is not just a plant. It is a plant attached to a crack on a concrete or brick surface. That is its contemporary botanical image, with doses of fear tightly associated to it.

${ }^{22}$ Ian Rotherham, 'History and Perception in Animal and Plant Invasions: The Case of Acclimatization and Wild Gardeners', in Rotherham \& Lambert, Invasive and Introduced Plants and Animals, 243. 


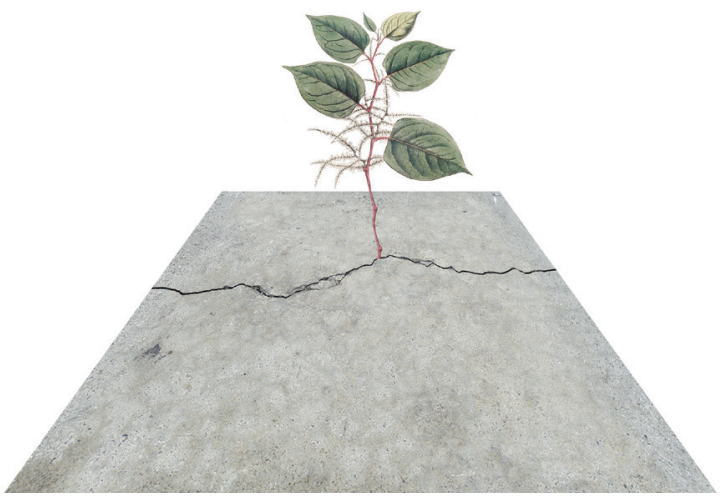

Figure $2^{23}$

If, to follow the idea of objectivity according to science historians Lorraine Daston and Peter Galison, the botanical image is a clear means of production of truth. Eighteenth-century atlas illustrators had the authority to define what is the image of a plant; what is the perfect image of the plant. The ideal. The average. The normal. Goethe's Urpflanze. ${ }^{24}$ But that image is so idealised that it actually does not exist, as it carries features of many specimens, put together in an impossibly true way to distribute certain kind of 'objective' knowledge. Botanical drawings traditionally overlapped different time cycles simultaneously, to represent growth and death, blossoming and decay, through the production of fictional images that tamed nature at a pictorial level.

${ }^{23}$ Different lobbies have pushed for associating the image of knotweed to a crack on a concrete surface. Illustration: the authors, 2016.

${ }^{24}$ Lorraine Daston and Peter Galison, Objectivity (Brooklyn, NY: Zone Books, 2007), 69. 
The image of a plant condenses scientific and/or economic interests around it. Today the image of a concrete crack is almost inseparable from Japanese knotweed, which has turned it - and other 'non-native' 'invasive' plants - into fully anthropogenic species that pose a menace to society. However, it can be questioned whether Japanese knotweed poses a real threat, and whether it can penetrate through a $30 \mathrm{~cm}$ thick slab of concrete: is knotweed really producing the crack, or was the crack already there and the plant grew through it, like any other plant? According to John Bailey, the media often claims that knotweed can grow through concrete, without any evidence of this. It is true that knotweed can grow through a gap in concrete or a gap between brickwork and concrete, but so can many other plants. Repetition of this claim does not make it any truer. ${ }^{25}$

Eradication companies aim to kill the plant with pesticides, glyphosate and injections. None of them has so far achieved the ultimate goal, as it seems that the 'pest' cannot be made to disappear, but lives on to perpetuate the lucrative business of eradicating 'non-native' invasives'. In an elaborated report for customers seeking to get rid of the plant, one example of advice given sustains the scaremongering strategy:

During the survey it was noted that there was a significant infestation of mature and healthy Japanese knotweed within an adjoining garden with further Japanese knotweed located on the private garden of the subject property. Japanese knotweed is

${ }^{25}$ John Bailey, public lecture at CCA Glasgow, 6 May 2016. 
designated as an invasive species by the Environment Agency and is a structurally damaging plant able to penetrate a range of surfaces and structures. Planning permission and many mortgages are declined due to the incidence of uncontrolled Japanese knotweed in or close to subject properties. ${ }^{26}$

Mortgage lenders often refuse to lend on property with knotweed, or close to knotweed infestations. ${ }^{27}$

Their use of language reiterates toxicity and contamination to stress the urgency of eliminating the plant: 'It is essential to eradicate all of the infestations otherwise the client's site will be re-contaminated in the near future.'28 It also borrows from the idea of intervention in military terms: 'We have an Operative in your area [...] and are enquiring as to whether you are needing another Knotweed treatment.' ${ }^{29}$ In addition, companies providing eradication services emphasise the shift of responsibility towards the owner: 'The legislation above puts a duty of care on the landowner with Japanese knotweed infestations to be proactive in the control and eradication of it.' ${ }^{30}$ Furthermore, new regulations influenced by the ongoing scaremongering are turning that proactiveness into a legal obligation. Otherwise, 'failing to control Japanese knotweed in one's property could result in an anti-social behaviour order and a fine of up to $£ 2,500$. $^{31}$

26 Eco Control Solutions, 12 December 2012.

27 PBA Solutions, 9 July 2013.

${ }^{28}$ Eco Control Solutions, 12 December 2012.

29 PBA Consulting Solutions to the authors, 30 August 2016.

${ }^{30}$ Eco Control Solutions, 12 December 2012.

31 'Fines for Failure to Control Japanese Knotweed', BBC, 19 November 2014, http://www.bbc.com/news/uk-30110654. 
It is impractical to try to restore ecosystems to some 'rightful' historical state. ${ }^{32}$ The public perception of 'native' and 'non-native' is constructed and subjective, as they are qualities attributed by man to the - less and less natural, and increasingly artificial - environment. Therefore, wars against 'invasive' species are impossible to be fought. A parallel stream of action that tackles 'nonnative' 'invasives' from a less xenophobic approach has aimed to include and embrace them into the everyday cycle of human diet as a means of gastronomic control. The idea of eating 'invasive' species is not new. ${ }^{33}$ Even if it can balance the rapid spread of certain species, it has been criticised for also posing some challenges, like creating markets of consumption that investors would be willing to continue or even encourage. Contrary to this, the idea of incorporating these plants into a diet is not about creating a trend that would worsen their spread, but to think of food as a cultural heritage with an expiration date. To declare them temporary national dishes until the ecosystem is rebalanced. To adapt our sense of taste to them rather than the law against them. Any plant has been 'non-native' 'invasive' at some point in the geological history of the planet; it is just a matter of years or centuries for us and other species to start learning how to turn them into part of a daily dietary cycle. ${ }^{34}$

32 Davis, 'Don't Judge Species on Their Origins'.

${ }^{33}$ Eduardo H. Rapoport et al., 'Edible Weeds: A Scarcely Used Resource. Bulletin of the Ecological Society of America 76 (1995): 163-166; Martín A. Nuñez et al., 'Invasive Species: To Eat or Not to Eat, That Is the Question,' Conservation Letters 5 (2012): 334-341; Scottish forager Mark Williams uses Japanese knotweed to distil local gin (Mark Williams in discussion with the authors, February 2016).

34 James Dickson in discussion with the authors, 27 February 2016. 
A remarkable example is the 'invasive' lionfish in the Cayman Islands that since the late 1980s has spread all across the Caribbean. A lionfish eats any other smaller fish and reproduces so quickly that it has overrun most reefs, threatening aquatic life and with it, the tourist diving industry. Lionfish have poisonous spikes, making them difficult to catch and only possible to be fished manually with a spear or harpoon. Their tasty meat has made the Caymanian government encourage people to catch and cook these fish. They have set regular tournaments awarding the diver catching the largest amount of fish in a day, and persuaded local restaurants to serve them as 'local' dishes. Within a few years the Caymanian government has recorded a reduction in numbers of lionfish since the initiative kicked off. ${ }^{35}$ Could gastronomic culture become a temporal practice with an expiration date - to eat lionfish until new ocean predators emerge or lionfish is no longer an ecological 'threat'? Centuries of accelerated mobility causing displacement and misplacement of species require forms of eating that have as much agency as legal frameworks to balance the environment.

Following the Caymanian initiative, The "Next "Invasive" Is "Native" was born as a project that questions negative definitions and taxonomies of 'aliens' that have been living in Britain for decades, centuries or millennia. Instead, could we integrate newcomers, misplaced and displaced edible plants, into an everyday form of eating? The project emerged as part of Pokey Hat, an exhibition that looked

${ }^{35}$ Authors in conversation with the Department of the Environment, Cayman Islands. March 2015 
at the socio-economic history of ice cream in Glasgow. ${ }^{36}$ The stigmatised public perception of Italian immigrants, who arrived to Scotland in the 1900s, was accentuated by an unprecedented wave of ice cream parlours they opened all across the city. These new venues effectively challenged the sexist Victorian morale and became 'sites of promiscuity', where women were able to socialise on their own till late at night. ${ }^{37}$ After three or four generations, ice cream has become a matter of national pride in Scotland. The project initiated a collaboration with five local ice cream parlours in Glasgow to produce ice cream out of 'non-native' 'invasive' species, like Japanese knotweed or Himalayan balsam, but also 'native' 'invasive' species, like nettles (brought to Britain by the Romans some two millennia ago, also from Italy). The recipes for the different ice creams were developed together with the descendants of the 1900s ice cream makers.

Yet in order to source the plants, the project had to operate within the laws criminalising 'non-native' 'invasive' knotweed, which forbid the spread of it, but do not affect the foraging of 'native' 'invasive' nettles. Cutting and throwing away knotweed rhizomes is forbidden on the basis that it can lead to new shoots, but the foraging of the plant for full consumption is undefined and can take place in a legal limbo. The acceptance of 'nonnative' species might happen through the cone, the palate or the plate but a transformation of the legal system that

${ }^{36}$ Pokey Hat was curated by VERBureau for Glasgow International in 2016.

37 'Ice Cream and Immorality', Glasgow Herald, 18 May 1906. 


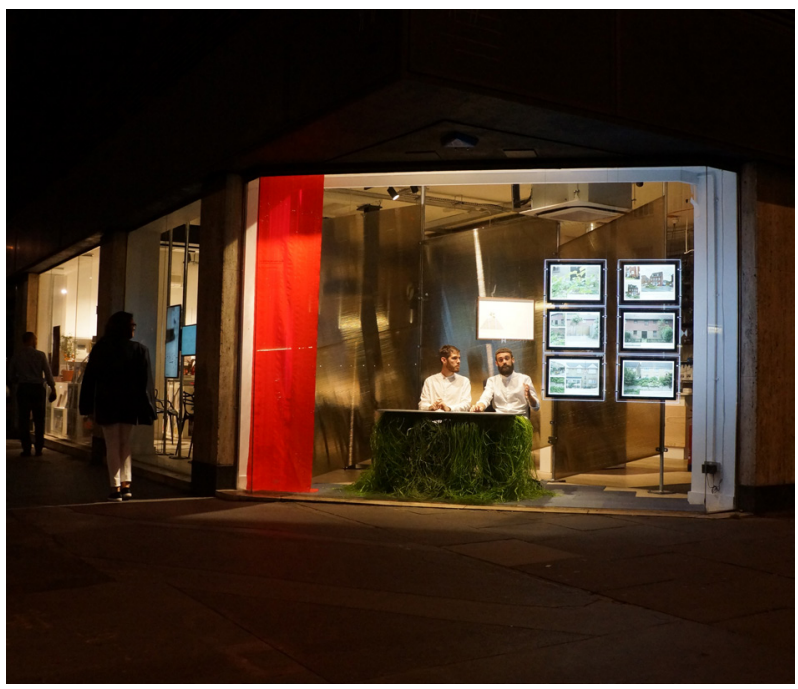

Figure $3^{38}$

criminalises them has to support the redefinition of who does or does not belong and what is to be tasted.

The second iteration of The "Next "Invasive" Is "Native" took place as part of The Empire Remains Shop, a platform set up by Cooking Sections to speculate on what it would mean to sell the remains of the British Empire in London today. Continuing the rationale challenging subjective laws regulating 'non-native' 'invasive' plants, the Devaluing Property Real Estate Agency followed as an installation for two weeks in September 2016.

${ }^{38}$ Devaluing Property Real Estate Agency, at The Empire Remains Shop in London. Photo: the authors, 2016. 
It responded to the context of the site, located on 91-93 Baker Street at the heart of Marylebone, a district left ghostly by overseas investors accruing valuable properties they will never occupy. ${ }^{39}$ It reacted to the omnipresence of real estate agencies, who are becoming real invaders in our cities and are profoundly damaging the housing environment in both their ethos and modus operandi. The Devaluing Property Real Estate Agency replicated the aesthetics of their window displays through LED lightboxes to compile and showcase a series of properties 'affected' and devalued by knotweed: properties whose owners committed suicide believing they had gone bankrupt after the plant appeared in their garden, or properties whose value simply dropped and became another market niche for buyers. A thirtyminute consultation session on how to devalue property through the agency of a plant was offered. Hundreds of people stopped by the window to look at the assets on display: some engaged with the topic, others ridiculed it, and others became infuriated for playing with such a serious business and stable pillar of society. As part of the consultation session, the agency of the plant materialised in the tasting of The Plant That Can Sink Your Mortgage Ice Cream.

If our sense of taste can adapt and make 'invasive' plants palatable, our borders can also evolve and mutate into a

${ }^{39}$ Hettie Judah, 'A Mock Pop-Up Critiques Britain's Imperial History', Artnet, 17 August 2016, https://news.artnet.com/exhibitions/ london-pop-up-shop-critiques-englands-imperial-history-609824. 


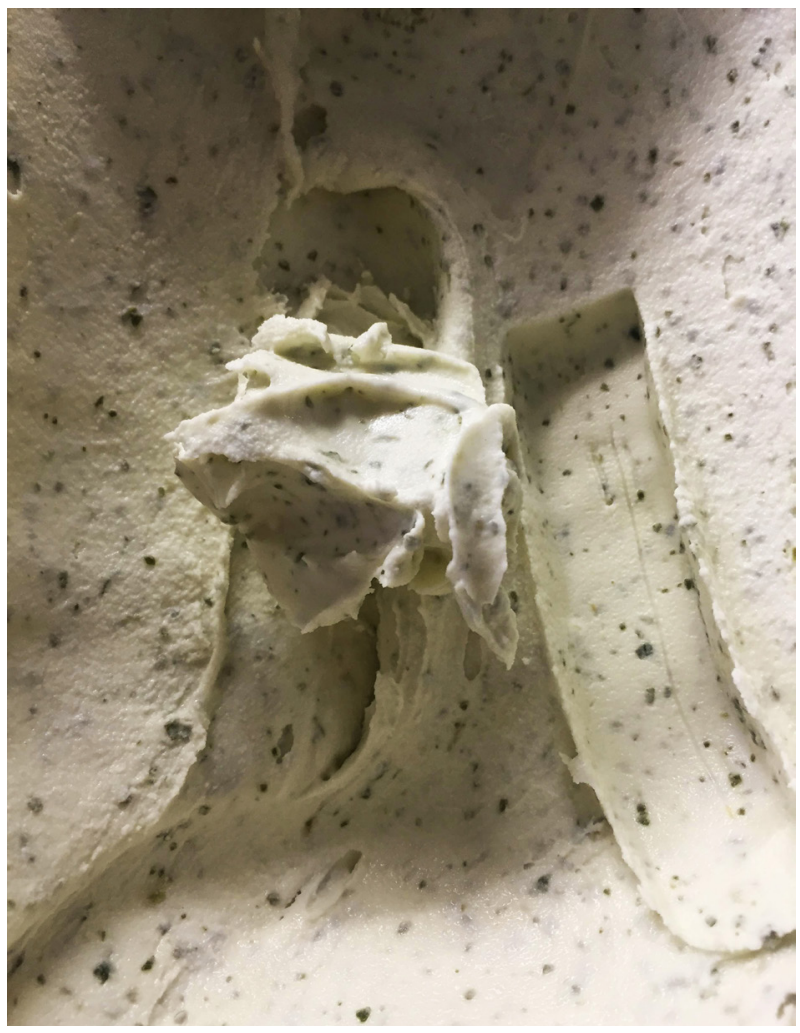

Figure $4^{40}$

blurry condition within a postcolonial world. Learning how to eat 'non-native' 'invasive' plants introduces tastiness as a form of habituation. Like in the case of the

40 The Plant That Can Sink Your Mortgage Ice Cream. Photo: the authors, 2016. 
tubers and vegetables brought from the Americas in the fifteenth century, the Italian ice cream makers in Scotland in 1900s, and the recent eating of lionfish in the Cayman Islands, Japanese knotweed as an ingredient can challenge normative perceptions of belonging and predetermined legalities around 'aliens'. Indeed, the sense of taste has been able to adapt throughout history and constantly blur the category of 'native' and 'non-native'.

This essay is based on The "Next "Invasive" Is "Native", a performative lecture by Cooking Sections at The Empire Remains Shop.

\section{References}

Bailey, J.P. \& Conolly, A.P. (2000). 'Prize-Winners to Pariahs a History of Japanese Knotweed s.l. (Polygonaceae) in the British Isles.' Watsonia, 23: 93-110.

Daston, Lorraine, and Peter Galison. Objectivity. Brooklyn, NY: Zone Books, 2007.

Davis, Mark. Invasion Biology. Oxford: Oxford University Press, 2009.

Davis, Mark A. et al. 'Don't Judge Species on Their Origins'. Nature 474 (2011): 153-4.

Dickson, J.H. Plant Introductions in Scotland. Species History in Scotland (ed R. A. Lambert), 1998, 38-44. Scottish Cultural Press, Edinburgh.

Dickson, J.H., Macpherson, P. \& Watson, K. The Changing Flora of Glasgow: Urban and Rural Through the Centuries: Urban and Rural Plants Through the Centuries, 2000 Edinburgh University Press.

Nuñez, Martín A. et al. 'Invasive Species: To Eat or Not to Eat, That Is the Question.' Conservation Letters 5 (2012): 334-41. Pearce, Fred. The New Wild: Why Invasive Species Will Be Nature's Salvation. London: Icon Books, 2015. 
Pimentel, David et al. 'Economic and Environmental Threats of Alien Plant, Animal, and Microbe Invasions.' Agriculture, Ecosystems and Environment 84 (2001): 1-20.

Preston, Chris D., David A. Pearman and Trevor D. Dines. New Atlas of the British and Irish Flora. Oxford: Oxford University Press, 2002.

Rapoport, Eduardo H., Estela Raffaele, Luciana Ghermandi, and Laura Margutti. 'Edible Weeds: A Scarcely Used Resource.' Bulletin of the Ecological Society of America 76 (1995): 163-6.

Rotherham, Ian, and Robert Lambert, eds. Invasive and Introduced Plants and Animals: Human Perceptions, Attitudes and Approaches to Management. Abingdon: Routledge, 2013.

\section{Newspaper Articles}

'At War With Aliens', Plantlife, February 2000.

'Environet Media, http://www.environetuk.com/Media

'Fines for Failure to Control Japanese Knotweed', BBC, 19 November 2014. Accessed February 11, 2018. http://www. bbc.com/news/uk-30110654.

'Hidden Threat', RICS Building Control Journal, January 2014.

'Horror Weed on Rampage', The Glaswegian, 2001.

'Ice Cream and Immorality', Glasgow Herald, 18 May 1906.

'Japanese Knotweed Invasion Causes Hertfordshire Home Price Drop', BBC News, 27 Oct 2011. Accessed 11 February 2018. http://www.bbc.co.uk/news/uk-england-beds-bucksherts-15461880.

Judah, Hettie. 'A Mock Pop-Up Critiques Britain's Imperial History', Artnet, 17 August 2016. Accessed February 11, 2018. https://news.artnet.com/exhibitions/london-pop-up-shopcritiques-englands-imperial-history-609824.

'Kenneth McRae Killed Wife Jane and then Himself Over Knotweed Fears', BBC News, 13 October 2015. http://www.bbc. co.uk/news/uk-england-birmingham-34515446.

'Knot In My Backyard', AQD 62, summer 2013. 
'Stourbridge Man Killed Himself Over Japanese Knotweed Fears', Express and Star, 24 February 2016. https:// www.expressandstar.com/news/2016/02/24/stourbridge-man-killed-himself-over-japanese-knotweedfears/\#Gp2FclSEvukiExWA.99.

'The Garden Invader That Could Sink Your Mortgage', Around Town Magazine, summer 2015: 103.

'The Invader, If It's In Your Garden Panic Now', Times, 27 June 2000.

'The Plant That Can Cost You Your Home', Lovemoney, 25 June 2013.

Whitehall, Adam. 'Japanese Knotweed: Government to Issue Asbos to Those Who Fail to Deal with Invasive Plant', The Independent, 19 November 2014. http://www.independent. co.uk/news/uk/home-news/japanese-knotweed-government-to-issue-asbos-to-those-who-fail-to-deal-with-invasive-plant-species-9870356.html.

\section{Reports}

Eco Control Solutions, 12 December 2012, (name of client and site address remain anonymous).

Japanese Knotweed Alliance CABI, 'Establishing the Psyllid:

Field Studies for the Biological Control of Japanese Knotweed'. Accessed 27 September, 2017. http://www.cabi.org/ projects/project/32999.

PBA Solutions, 9 July 2013.

The Law Society, 'Property Information Form TA6', Question 7.8. 